\title{
The Paradox of Contemporary Play: The Dangers of Framing Play
}

\author{
Rene NOVAK | ORCID :0000-0001-6136-6418 \\ M.Ed; PhD candidate, Faculty of Education, University of Waikato, Hillcrest, \\ Hamilton, New Zealand \\ proronny@gmail.com
}

\begin{abstract}
This paper will elaborate on the different ways play is being framed in the contemporary western world and how framing play is making it susceptible to manipulation that employs it to work in contradiction with its core purposes. The author suggests a contemporary paradox that arises in the core of early childhood education concerning child's play. As play is a basic developmental function of mind and body common to all mammals, some important functions of play are going to be investigated. Due to the established fact that freedom to exercise play is of the outmost importance for a normal developing mammal from infancy to adulthood, this paper will focus on the reasons as to why people defy nature, by restricting its young in this basic form of activity and engagement, hindering their normal development, and ignoring that play carries vital epistemological and ontological human significance. Commercialisation of play alongside the disappearing time and space for free play in communities, at home, school and ECE centres will be accounted for as reasons for an erosion of play, alongside some influential ideologies of play.

Following form this the author investigates how framing play accounts for difficulties in empirical research of play, contributing to a lack of clear pedagogical, phenomenological and methodological answers about play and hence raises questions concerning a need for further phenomenological investigations of play alongside alternative methodological frameworks to 'see' beyond the elusiveness of play.
\end{abstract}

\section{Keywords}

play - commercialization - early childhood education 
Play is a basic developmental function of mind and body common to all mammals (Holst, 2017). Freedom to exercise play is therefore of the outmost importance for a normal developing mammal from infancy to adulthood. Yet humans are restricting its young in this basic form of activity and engagement, hindering their normal development, and ignoring that play carries vital epistemological and ontological human significance (Lewis, 2017).

Play has a multitude of important developmental functions, over 30 possible ones currently identified, enabling children to become competent and confident within the embrace of play's universal cultural right (Lancy, 2007). Jarvis et al. (2014) stress that the relatively recent erosion of play has severely decreased opportunities for children to engage in free play at ECE centres, schools, home and in the community and suggest a direct link with the declining mental health amongst many children. Such deprivation of an evolutionarily significant developmental function, if that link exists, results in a loss of socially developmental experiences that are raising levels of anxiety and mental illness, feelings of social disconnectedness, poor social skills and are on a greater scale accountable for a dysfunctional society.

Yet it is not due to ignorance that humans defy nature, as there is a great deal of empirical and scientific evidence stressing the importance of unobstructed child-led play; nevertheless, play has been severely eroded over the past two decades in the western world giving rise to an ambiguous paradox of contemporary play. Lewis (2017) offers four reasons as to why play is being eroded: commercialization of play through media; fear and safety concerns; standardisation of the curriculum; and ideological struggles around play. While the erosion of play is happening through a multitude of landscapes and while some kinds of play are more affected than others, the following sections will argue that these reasons for decline in time and space for play can be associated with play's ambiguous nature.

Play is regarded as being universal, broadly identifiable, but very difficult to explicate; therefore it is perceived as an elusive term which defies all conceptualisation (Lewis, 2017). These challenges of the multifacetedness of play are also reflected in the educational practice as Whitebread \& O'Sullivan note: 'The field of early childhood education is permeated with ambiguity around 
how adults should engage in child-initiated play,' (2012, p. 207). One of the predominant explanations of this problem is rooted in Piagetian child-centred philosophy that views play in a progressivist way arguing that it supports stage by stage temporal development. Even though this view has been largely criticised it is still embedded in contemporary ideology of play.

The fact that theoretically determining play seems to be a futile endeavour and that play cannot be tied down by one possible explanation or definition perhaps becomes clearer if we view play as a phenomenon that receives its impulses from life itself (Holst, 2017). If life arguably should not be considered an object, then perhaps the same standard should apply to play. When play is framed it is in most cases regarded as an object and when play is gazed upon as an object it becomes an illusion of itself and it takes a ludic form for the eye of the beholder (Larsen, 2015) - ludic in the sense of a careless act of following playful impulses that exhibit no apparent reasoning and meaning behind it. The philosophical dilemma that arises from this thinking is complicated by the issue of how play can be described rationality and scientifically if not as an object.

Most scientists, researchers and policy makers in education constitute play from their own perception, hence their explanations, field of research and research results are also determined by their chosen and applied ideology (Larsen, 2015), rendering play a highly subjective phenomenon that becomes easy to bend to one's own agenda, as its fluidity permits it to be applied in multiple ways. The diversity of emergent contemporary discourses of play can be reduced to this banal version of play that leaves it vulnerable to be used in malicious ways and for purposes that defy its basic purpose and function. When examiners are positioning themselves outside the dynamics of play what they are really researching is the illusion play offers rather than play itself. If we consider this assumption true, then the explanation for the elusiveness of play could itself be accounted for in the following: that people engaging with play's elusiveness are in fact engaging with an illusion of a phenomenon rather than the phenomenon itself. Perhaps a further philosophical examination of this perplexing issue can give rise to a solution.

Brooker (2011) stresses that researchers should start listening and observing children in their own play and take children's own perspectives on/of play more seriously - in other words, they should source the information about play from the players, who operate under the illusionary blanket and beyond the elusiveness of play: 'If educators and researchers ignore children's own play agendas, and focus on their own, they will be unable to support the important meanings play holds for children' (Brooker, 2011, p. 142). A Dutch philosopher says that play creates borders where time and space act differently from the 
outside (Huizinga, 2004) further explaining the reasons of the existence of an illusion that takes place when observed from the outside. From this perspective it is as if the beholder would be looking at a time-space aberration struggling to conceive what is happening.

This raises the question of what this blanket, border, frame we are talking about is and how this layer in between the observer and the children at play comes into existence.

Ironically some researchers who are examining the clockwork of play (Butler, 2010; Lewis, 2017; Whitebread \& O'Sullivan, 2012) are calling it the 'play frame', as framing play has been attempted numerous times, yet the possibility that play is framing itself was not considered. It is this self-established frame that reflects the gaze of the observers with a misapprehension like a protective shell. It becomes a boundary of real and imaginary where children can realize their freedom, joy and passion (Vandenberg, 2004, p. 58). The play is established within the play frame when children commence playing and the rules for membership within it are set.

Observers can experience the play frame and more importantly, they can enter it if they so desire by assuming a character and by understanding that play is an unnatural freedom established by the rules and constraints that become internal to play (Ohaneson, 2017) observers can use this knowledge to become participants. Play plays out through the participants (Larsen, 2015); hence, its true nature is only revealed to the participants. If researchers would become more considerate of these facts perhaps the dynamics of play would not be as unclear as portrayed.

Due to the ambiguity of a play-based curriculum many are finding it hard to assess learning outcomes derived from free play (Niles, 2015; Novak, 2019), resulting in play becoming increasingly more intellectualised and its outcomes further standardised. Perpetuated by the educational trend in the western world of only valuing what can be framed and assessed, whilst one of the basic functions of human development is being eroded globally and nationally through the capture of play.

This section will endeavour to explain how framing play enables the rise of various misconceptions and misrepresentations about it and how they cause erosion of play. These notions are going to be discussed through play being eroded by commercialism and by the demising time and space to play effected by a number of misapprehensions of play. 


\subsection{The Commercialisation of Play}

This part will highlight how play is being commercialising and raise the issue that parent and children are unaware of it. A number of media corporations took it upon themselves to impose children and parents with their version of play and disguising their neo-liberal agendas of transforming an inquisitive wonderer at play into a compliant consumer behind the misleading innocence of play whilst drawing on current neuro-scientific research to maximise their profits (Sun, 2002).

Since the 1980's marketers have started to spend millions of dollars on enlisting child psychologists and their research to construct the child consumer (Reifel \& Brown, 2004) with the agenda being supported by the power of media. The corporatisation of play has now reached its peak as large-scale organisations such as Disney have 'refined and perfected its pedagogical influence' (Lewis, 2017, p. 12) through TV shows, movies, books, amusement parks, toys and computer games exclusively for child consumption. Hence commercial empires become the new teachers of the millennium where they majorly inform, and form play for children and their parents and teach them how to play the neoliberal game of becoming a citizen of consumerism, which translates as teaching them how to think through hidden discourses embedded in their products (Kasturi, 2002). The major discourse mediated is the discourse of consumption and instilling their targets with the traits and habits of becoming a consumer though the materialisation of the 'Pedagogy of Desire'.

Many children quickly learn that to be popular with their friends in play they will need to have the latest toys and gadgets, have watched the latest movies and TV shows that inform their script of play, their imagination and thinking. Pretence play through imitation framed and constrained by the narrative of the media erodes authentic pretence play where the later has been proven to have considerably superior developmental values as it enables divergent thinking, creativity, innovative ideas and entrepreneurship (Kasturi, 2002). Furthermore, taking a closer look at the broadcasted media and their products reveals the marked emergence of another restrictive discourse. Ideologies of femininity are coloured in pink and purple, occupying smaller spaces at shops with an emphasis on babies and dolls; masculine, primary coloured high-tech metallic toys sit in large spaces at the fronts of the stores for boys.

The collective effects of commercialisation of play on children are increase in narcissism, anxiety, depression and the resulting sensation of poor wellbeing in later childhood and adolescence. With children spending a lot of time consuming the media, time and space for them to play have consequently diminished; however media is not the only cause of this kind of erosion (Jarvis et al., 2014). 


\subsection{Diminished Time and Space to Play}

A number of factors amount to the concerning fact that time and space for free unobstructed play are being diminished. Children are not presented with nearly enough time and space where social play is not thick with observation and surveillance, or as Marjanovic-Shane and White (2014) put it 'when the footlights are off'. It is through unobstructed social interactions away from the gazes of the adult that play reveals itself fully to the player while the developing factor for the child is the highest and when play is at its most effective. Children's play is influenced by the presence of adults, as they are aware of the social and cultural constraints and expectations enforced by adults. With an absence of peer-to-peer play children fail to acquire the social and emotional skills needed to develop healthily, physically and psychologically (Jarvis et al., 2014).

Karsten (2005) suggests that the overall decrease of social interactions between children has also been affected by many families becoming working families and by altered communal perceptions where neighbourhoods are not deemed safe anymore for children to inhabit unsupervised. Parents are also showing a preference for their children to indulge in structured sports games rather than free play, while teachers are discouraging certain kinds of free play such as 'rough and tumble play' and 'war play'. All these contemporary ways of re-framing play combined together create a 'social trap' (Karsten, 2005, p. 222) for children, severely inhibiting many kinds of play and are gong to be examined individually next.

\subsubsection{Changing Communal Perceptions of Play}

Over two decades ago opportunities for collaborative free play were plentifully catered for by the local community and neighbourhoods and the people inhabiting them (Jarvis et al., 2014). The outdoor was freely available to many children as the communities were deemed safe and a place where neighbours were looking after each other (Brown \& Patte, 2012; Sutton-Smith, 1997) and the children were able to become increasingly more independent and develop relationships and learnt the rules of engagements in social interactions. A feeling of belonging was instilled in them as they took part in constant social exchange in the world around them. Out of school outdoor spaces were plentiful and full of children playing a variety of street games.

Brian Sutton-Smith, internationally celebrated theorist and ambassador of free play, told a very similar story about his childhood on the streets of Wellington, New Zealand at an interview recorded by Brown \& Patte (2012). He talked about the adventures he went on with his friends and the many influential experiences he engaged/was involved with socially when time and space 
for free play were plentiful. Children were free to explore their surroundings while developing important social skills and developing an understanding of the world that surrounds them. While the sense of freedom and trust was experienced by them they were not absent of supervision, but it was a lot less intense. Neighbourhoods collectively took on the responsibility to ensure the safety of the children in their community through a form of communal supervision.

This kind of freedom has nowadays become scarce for numerous children (Sutton-Smith, 1997). Many neighbourhoods have become overrun by busy and often dangerous roads, sensationalized news of accidents or incidents concerning children gradually increased the fear factor in parents and suddenly the neighbourhoods where not deemed safe enough for children to roam around without adult supervision, resulting in an adult colonization of children's lives, that brought about an overwhelming decrease of time and space for children to independently engage in social free play.

Communities provided for a space to engaged in unstructured social play, which has lately increasingly more transformed into adult organised games, where parents are under the impression that children are receiving the same or better benefits than they would from free play.

\subsubsection{When Games Consume Play}

Sport leagues for children are being chosen by the parents and are increasingly replacing the opportunities for children to negotiate and create their own culture of play within a socio-cultural environment of choice (Jarvis et al., 2014). While these forms of adult orchestrated play are preferable for parents, research warns of the implications this kind of erosion of play has on child development: Huizinga (2004), for instance, posits that homo sapiens (the man who knows) can only fully develop through homo ludens (the man who plays).

This paper is stressing that there is a marked difference between play and games, even though games are a subset of play. Types of games manifest themselves in play through to contrasting attitudes: paidia (turbulence, free improvisation, and carefree gaiety) and ludus (frolicsome and impulsive with discipline and convention) (Mäyrä, 2008). Yet the distinctive difference is that play involves make believe, but a game is a closed, formal system that engages players in structured conflict and resolves its uncertainty in an unequal outcome (Walton, 1993). Games share their commonalties with play in as much as they are entered freely and voluntarily, they involve repetitive actions to-and-fro where the rhythm of play is embedded in games and the pleasure of play is also manifested (Buytendijk, 1976). The traits that play does not share with games constitute make-believe; play has no goals, challenges, or structured conflict, 
its rules are not laid out in advance and there are no uncertain outcomes that favour someone. Hence the developmental outcomes play in general constitutes are going to be much wider in scope, more in depth and will lay claim to much stronger gains. Parents perceiving sports as a version of good play is only one example of where play is being viewed as good or bad.

\subsubsection{Good Play and Bad Play}

Free play where children are able to negotiate their own culture of play, such as mentioned communal social play, has significant social and developmental implications for their development (Mäyrä, 2008). Rough and tumble play (RTP) is of importance for developing a social and hierarchical understanding between boys, yet this kind of play is routinely categorized by adults as 'bad play'. Often, play is looked at as 'good play' (Sacred Play) when it leads to orderly attainment of desired goals and as 'bad play' (Festive play), when it stems from children's interests and needs, categorized as disorderly and subversive (Sutton-Smith, 1997). RTP reduces genuine aggressive behaviour and supports the development of socio-cognitive skills not acquired in other kinds of play such as social intelligence and certain working theories of the mind (Jarvis et al., 2014). Children involved in RTP are also able to distinguish play from real aggression and vice versa, whereas children whose RTP has been restricted by adults are often observed in displaying real aggressive behaviour as they are unable to distinguish between pretend play and real aggression. The strong bias against active, aggressive behaviours and speech mostly arises from feminisation of the pedagogical context of play where it is paramount to keep up the appearances of schools and ECE centres as calm and peaceful environments. Research tells us that only $1 \%$ of RTP results in a real fight (Smith, 2010). The one rule of play that even animals abide by is to avoid seriously injuring your play mate - a form of respect imbedded in play itself at its most basic level (Holst, 2017). RTP is observed with all young mammals and research supports that this kind of play establishes important neural connections within the areas of brain that regulate emotion and sociability. In this sense RTP enables young mammals to fine tune their behaviour with peers and hence alter brain functions that constitute social skills.

Comparable inclinations can likewise be observed in ECE and school environments, where games are more important as play. Further important considerations of institutionalised play are going to be described next.

3.2.4 The Demise of Time and Space for Play at Educational Institutions In many countries of the western civilisation, very young children's activities are being structured moment to moment in the name of 'becoming school 
ready' in contrast to support 'play based discovery learning opportunities with open agendas' (Jarvis et al., 2014, p. 57) where children can build their understanding of the world from the through people-based interactions rather than in separate storage areas residing in the individuals. This regime is underpinned by the vigorous and regular testing of academic skills, in particular literacy and numeracy, mandated by the increasingly detailed instructions of the governments on what and how to 'teach'. The perception that children under the age of five need to be implanted with learning from every discipline through planned and purposeful activities have left many playgrounds of preschool services quiet through the day (Miller \& Almon, 2009). A similar picture is observed at schools where every minute of the school day is being utilized with purposeful adult-guided learning to meet the requirements of the curriculum, resulting in break times that used to be dedicated to free play becoming shorter and scarcer (Lewis, 2017). In schools, short term gains in standardized testing now outweigh the need to acquire long term educational gains which are directly reflected in ECE institutions as an unsubstantiated need for setting goals of readiness. Once the goal of 'readiness' is set in any early education policy, the play-based teaching and learning practices traditionally offered within statutory education for children under seven are usually replaced by an academic preschool curriculum.

The erosion of time and space for free play in learning institutions is closely associated with another kind of erosion as the 'school readiness' phenomenon has illustrated: with the erosion of play in the curriculum.

\subsubsection{Framing of Play in the Curriculum}

Today's push for standardized testing in the western world and the willingness to mould curricula to serve this agenda is irreconcilable for any ECE philosophy. Such testing has risen in the shadow of neo-liberal discourses that are framing play as a tool for teaching and hence inadvertently indulging in the act of intellectualisation of play (Fuller et al., 2017). Standardized learning outcomes and the intellectualising of play in curriculum documents are causing an erosion of play.

Curricular frameworks (UK, USA, NZ) acknowledge the value of play at a theoretical level, yet implementing an effective pedagogy of play can be problematic (Lewis, 2017; Whitebread \& O'Sullivan, 2012). This may be due to the concept of 'learning through play' being enshrined in these documents even though the research that there even is such a notion as 'learning through play' is quite inconclusive. Learning through play often misleadingly claims the beneficial implications play has on the development of humans with its many well-researched, supported functions in the scholarly community. While the 
rhetoric of play is alive, play itself has become highly structured, under the gradual standardisation of ECE curricular documents to ensure there are learning goals to be met (Sevimli-Celik, 2017). Through this the authenticity of play has become eroded as authentic play requires the absence of an adult unless the adult is a co-player where the goals of play remain with the children. Hence in many countries play has become institutionalized in ECE (Lewis, 2017). This is reflective of the Cartesian outlook and approach that still keeps a strong hold on people's minds (Holst, 2017). Seen from a strict scientific and analytical point of view, ludic activity appears to be irrational and meaningless; hence, play needs to be rationalized and institutionalized for it to take on a meaning that caters for the current rhetoric of play. Again, a link can be drawn between the ambiguity of play and its erosion.

Te Whäriki (MoE, 1996) has been a widely celebrated curriculum document nationally and internationally for its ingenuity, openness and the ability to be applied to any cultural context due to its positioning in the socio-cultural paradigm and the bicultural environment of Aotearoa (Stover et al., 2010). While its philosophy of openness was celebrated by many (Novak, 2013), this same philosophy was used against it when the document was scrutinized. The curriculum alongside its suggested framework for assessment (Carr \& Lee, 2012) was seen by some as too open to successfully evidence their success of progressing learning and achieving learning outcomes. The curriculum included 127 possible learning outcomes that the teachers could work towards, giving them a range of possibilities of how to articulate learning that occurred in free play experiences. Critics suggested that there were too many goals and that the applications of the curriculum in the context of free play were too wide to measure its success, portraying neo-liberal agendas. Hence the 2017 update of the curriculum (MoE, 2017) standardized the learning outcomes of the document to 20 with a stronger neo-liberal focus on the 'School Readiness'. The initial draft included statements about learning letters and numbers and was not received well by many in the ECE community during the very short consultation period. The final draft amended the wording; however, the outcomes still retained a certain amount of implied academic learning that should occur through play, giving way to an intellectualisation of play.

Intellectualising play and the need to mould play to abide to the curricula have got their roots in the progressivist ideology of play which is going to be described next.

\subsection{The Progressivist Rhetoric of Play}

When regarding play from a genealogical perspective one cannot get past Sutton-Smith's (1997) historical categorisation of play ideologies, or as he named 
them 'rhetorics of play'. He proposed that at any point of time play as an ideology has also been play as a discourse mediated through the positioned rhetoric of play. Sutton-Smith defined play as a heterogeneous phenomenon that relies on the eye of the beholder (Larsen, 2015) and building on that definition he theorised that the rhetorics are illustrating a particular view on play in history. He proposed one of the core messages within this thesis: that an inquisitor of play needs to be able to step outside their own culturally constructed understandings (frames/rhetoric's) of play and begin to listen to children, and parents, about their own notions of play and learning, especially cross-culturally. He recognised that play means different things across cultures as it is a culturally structured activity and he understood the cultural changes through time that constituted his genealogical model of play, where play cannot be discerned outside the socio-cultural frames that have been constructed by and for us (Lewis, 2017).

The most important rhetoric in terms of capture of play is the rhetoric about 'Progress', as the genealogical influences of this ideology are still strongly entrenched in the western world and are a major contributor to the erosion of play. The progress rhetoric argues that play is a developmental process of children and animals, but not adults. It has dominated Euro-American thinking more as a belief than a demonstrated fact: that children's play is about development and particularly learning rather than enjoyment (Sutton-Smith, 1997, pp. 9-12). This ideology has manifested itself in parents, teachers, policy makers and many scholars and is therefore to blame for many misconceptions about play (Smith, 2010). It permeated ECE and school curricula with its discourses as well as the media and the neo-liberal market agenda (Lewis, 2017).

The problem stems from narrow interpretations of Piagetian child-centred temporal development philosophy (Whitebread \& O'Sullivan, 2012). Yet several other theorists contributed to this rhetoric also. Froebel's 'gifts' and occupations and his play curriculum is one of the earliest forms of standardized, orchestrated play for children (Reifel \& Brown, 2004). It has been redeveloped by Maria Montessori's philosophy about progression of learning through a mass of adult pre-selected materials to do 'work' with. Another progressivist - John Locke - was the father of 'sacred play' where he actively discouraged children's play outside and presupposed that children are better off inside the house with the alphabet. Progressivists shifted the historical context from a play attitude to a work attitude or in other words they changed the rhetoric of play from the rhetoric of 'Self' that emphasises the desirable experiences of players such as the fun, enjoyment, pleasure, joy - and the intrinsic or aesthetic satisfactions of the play performances - to the rhetoric of 'progress'. Ever since, the reputation of play did not recover as the importance of play for/as learning is still paramount, even though this is not clearly supported by research. 
In summary as deducted above several factors currently pose an immediate danger to free play seen in the decreased time and space for free play. Standardisation of learning outcomes suggests an intellectualisation of play in ECE curricula. Commercialisation of play by certain media corporations continues to frame play in unregulated ways. The progressivist rhetoric continues to persist in many people's understandings about play, where parents, policy-makers and even teachers are framing it with an unconscious bias.

Nevertheless, there is still hope for free play. One could even say that even though it is being eroded it is putting up a fight. Brian Sutton-Smith (Brown \& Patte, 2012) noted that children find time and space to play in the most adverse of times. They still manage to find or invent openings, spaces to engage in the forbidden - self-directed, festive, ludic and illicit play as soon as 'the footlights are off' (Jarvis et al., 2014; Lewis, 2017; Marjanovic-Shane \& White, 2014). It seems like play is at the basic core of human nature and it is not going to let itself be stilled, but what this paper stresses is that there should not be a struggle here to begin with. Adults are essentially destroying their inherent nature as much as they are currently destroying it around them. Perhaps the best way to start living in harmony with nature is to embrace the nature inside us and more importantly give our young the time and the space to live in congruence within themselves and with others through untainted free play. But to realise this vision many circumstances regarding play would need to change.

\section{Conclusion}

In the current context of early childhood education, play and learning are almost synonyms in curriculum terms, even though 'learning through play' is a concept that has not yet been established by empirical evidence (Whitebread \& O'Sullivan, 2012). The progressivist rhetoric of play and its discourses have been well established in adult minds and along those beliefs so have educational practices (Sutton-Smith, 1997). While western curriculum documents confidently assert that play should be 'used' as a vehicle to achieve its learning outcomes, the actual academic theory about how adults should engage in child-initiative play in the field of ECE is permeated with ambiguity (Stover et al., 2010). The research on adult involvement in play is inconclusive, pointing to both positive and negative potential of adult intervention. Contemporary learning theories such as Vygotskian and Neo-Vygotskyan suggest a broad and integrated approach to pedagogy where the adult involvement should be sensitive in its nature as it can enhance developmental outcomes if the ownership 
of play stays with the children (Whitebread \& O'Sullivan, 2012). In such engagements children would be setting their own 'zone of proximal development' by setting their own level of challenges. Children's feelings of control alongside a provision of emotional warmth and security will enable effective cognitive challenges and stimulate their development.

Play is not only being used as a tool for education; adults are also determining which kinds of play are 'good play' and which are 'bad play', hence favouring pretend and socio-dramatic forms of play as they appear to benefit the learning while there is no room for RTP, physical and war play as discussed earlier. Adults' desire to organise children's free time in every possible way (Sutton-Smith, 1997) blinds them to the fact that children still get benefits from, and that they enjoy, the kinds of play adults disagree with. They often exert their power and control over children by limiting opportunities for unstructured non-adult supervised play (Lewis, 2017). For play to stop play in its natural course submerged in its rhythm to-and-fro something has to block it from continuing to unfold itself (Holst, 2017). Usually the obstructions are rules forged by adults. Play at its most elemental is not bound up with, but rather free of, fixed, prescribed rules. There may be rules while playing but they are set by the players and can only be changed by them as desired.

A number of studies suggest that more teacher play training is needed in playful approaches, designing play environments and pedagogical decisions, techniques and strategies involving play (Lewis, 2017; Sevimli-Celik, 2017; Whitebread \& O'Sullivan, 2012). When teachers are able to understand that play naturally encompasses all educational learning and development, not just the predetermined academic learning outcomes, they might start to value play as a self-actualising learning tool (Connell \& McCarthy, 2014).

While a vast amount of research about play is available, this paper and others have highlighted that a more philosophical and phenomenological lens on studying play is required to fashion new understandings about its ambiguous nature (Ohaneson, 2017). Consequently, reliable methodologies and methods to research and analyse play efficiently are also being sought (Raphael-Leff, 2009). Literature also suggests that play can only be comprehensively understood when the beholder becomes actively involved with play as an experience (Whitebread \& O'Sullivan, 2012); however, play studies are usually positioned outside the play experience while framing it from a certain predetermined play ideology (Sutton-Smith, 1997) that additionally restricts the researcher to see past their own rhetoric of play. This paper therefore concludes that the ambiguous nature of play in part originates in the lack of engagement of research(ers) with the actual play experience, while pre-framing it. 


\section{References}

Brooker, L. (2011). Taking Children Seriously: An alternative agenda for research? Journal of Early Childhood Research, 9(2), 137-149. https://doi.org/10.1177/147671 8X10387897.

Brown, F., \& Patte, M. (2012). From the Streets of Wellington to the Ivy League: Reflecting on a lifetime of play. International Journal of Play, 1(1), 6-15. https://doi.org/ 10.1080/21594937.2012.658166.

Butler, J. (2010). Frames of War: When is life grievable? (Pbk. ed). Verso.

Buytendijk, F. J. J. (1976). Wesen und Sinn des Spiels. Arno Press.

Carr, M., \& Lee, W. (2012). Learning Stories: Constructing Learner Identities in Early Education. https://nls.ldls.org.uk/welcome.html?ark:/81055/vdc_100025411755. oxooooo1.

Connell, G., \& McCarthy, C. (2014). A Moving Child is a Learning Child: How the body teaches the brain to think (birth to age 7). Free Spirit Publishing.

Dewey, J. (1986). Experience and Education. The Educational Forum, 5o(3), 241-252. https://doi.org/10.108o/o0131728609335764.

Fuller, B., Bridges, M., \& Pai, S. (2007). Standardized Childhood: The political and cultural struggle over early education. Stanford University Press.

Holst, J. (2017). The Dynamics of Play - back to the Basics of Playing. International Journal of Play, 6(1), 85-95. https://doi.org/10.1080/21594937.2017.1288383.

Huizinga, J. (2004). Den lekande människan: (Homo ludens). Natur och Kultur.

Jarvis, P., Newman, S., \& Swiniarski, L. (2014). On 'Becoming Social': The importance of collaborative free play in childhood. International Journal of Play, 3(1), 53-68. https://doi.org/10.1080/21594937.2013.863440.

Johnson, J. E., Christie, J. F., \& Wardle, F. (2005). Play, Development, and Early Education. Pearson/A and B.

Karsten, L. (2005). It All Used to be Better? Different Generations on Continuity and Change in Urban Children's Daily Use of Space. Children's Geographies, 3(3), 275290. https://doi.org/10.1080/14733280500352912.

Kasturi, S. (2002). Constructing Childhood in a Corporate World: Cultural Studies, Childhood, and Disney. In Kidworld: Childhood Studies, Global Perspectives, \& Education (pp. 39-45).

Lancy, D. F. (2007). Accounting for Variability in Mother-Child Play. American Anthropologist, 109 (2), 273-284. https://doi.org/10.1525/aa.2007.109.2.273.

Larsen, L. J. (2015). Play and Space - towards a formal definition of play. International Journal of Play, 4(2), 175-189. https://doi.org/10.108o/21594937.2015.1060567.

Lewis, P. J. (2017). The Erosion of Play. International Journal of Play, 6(1), 10-23. https:// doi.org/10.1080/21594937.2017.1288391. 
Marjanovic-Shane, A., \& White, E. J. (2014). When the Footlights are Off: A Bakhtinian interrogation of play as postupok. International Journal of Play, 3(2), 119-135. https:// doi.org/10.1080/21594937.2014.931686.

Mäyrä, F. (2008). An Introduction to Game Studies: Games in Culture. SAGE Publications Ltd https://doi.org/10.4135/9781446214572.

Merriam-Webster Dictionary. (2018). Definition of LUDIC. Merriam-Webster. https:// www.merriam-webster.com/dictionary/ludic.

Miller, E., \& Almon, J. (2009). Crisis in the Kindergarten: Why Children Need to Play in School. Alliance for Childhood. https://files.eric.ed.gov/fulltext/ED504839.pdf.

Niles, A. (2015). Assessment Practices within New Zealand Early Childhood Settings. $4(2), 11$.

Novak, R. (2013). The School of Open Education. Unpublished Masters Dissertation, University of Waikato.

Novak, R. (2019). Alternative Modes of Planning Using Storypark. The First Years, 21(1), 28-36.

Ohaneson, H. C. (2017). Philosophical Perspectives on Play. International Journal of Play, 6(2), 238-240. https://doi.org/10.1080/21594937.2017.1334324.

Raphael-Leff, J. (2009). The" Dreamer" by Daylight: Imaginative Play, Creativity, and Generative Identity. The Psychoanalytic Study of the Child, 64, 14.

Reifel, S., \& Brown, M. H. (Eds.). (2004). Social Contexts of Early Education, and Reconceptualizing play (II). Elsevier JAI.

Sevimli-Celik, S. (2017). What is the State of Play? Awakening Minds to Move and Play. International Journal of Play, 6(2), 128-130. https://doi.org/10.1080/21594937.2017 .1348288 .

Smith, P. K. (2010). Children and Play. Wiley-Blackwell.

Stover, S., White, E. J., \& Rockel, J. (2010). Hunting the Snark: The elusive nature of play. The First Years, 12(2).

Sun, C. (2002). Mickey Mouse Monopoly [DVD]. Media Education Foundation.

Sutton-Smith, B. (1997). The Ambiguity of Play. Harvard University Press.

Sutton-Smith, B. (2008). Play Theory: A Personal Journey and New Thoughts. American Journal of Play, 1(1), 80-123.

Vandenberg, B. (2004). Real and not Real: A vital developmental dichotomy. In Children's play: The roots of reading (pp. 49-58). Zero to Three Press.

Walton, K. L. (1993). Mimesis as Make-believe: On the foundations of the representational arts. Harvard University Press.

Whitebread, D., \& O'Sullivan, L. (2012). Preschool Children's Social Pretend Play: Supporting the development of metacommunication, metacognition and selfregulation. International Journal of Play, 1(2), 197-213. https://doi.org/10.1080/215949 37.2012.693384. 